\title{
PENGARUH MODEL PEMBELAJARAN INKUIRI TERBIMBING TERHADAP PEMAHAMAN KONSEP IPA DENGAN MENGONTROL MINAT BELAJAR PADA SISWA KELAS V SD
}

\author{
Ni Luh Gd. Kartika Kusuma Dewi, Dw. Nym. Sudana \\ Jurusan Pendidikan Guru Sekolah Dasar, Fakultas Ilmu Pendidikan \\ Universitas Pendidikan Ganesha, Jln. Udayana No. 11 Singaraja \\ e-mail: odekusumadewi @gmail.com
}

\begin{abstract}
This study was aimed to know the effect of guided inquiry learning model toward science concept understanding with controlling interest in learning. The research using non-equivalent post-test only control group design. The population of this research was all of the fifth grade student in elementary school belonging to the Group XIII of Buleleng district in academic years 2015/2016. The sample was taken out of two classes using simple random sampling. The collected data were analyzed by one way Ancova with one covariable. The results showed that (1) there are significant differences of science concept understanding between the group of student who studied with guided inquiry learning and the group of student who learned with conventional learning $(F=39,297$, with Sig. $=0,000<0,05)$; (2) there are significant differences of science concept understanding between the group of student who studied with guided inquiry learning and the group of student who learned with conventional learning after controlling the interest in learning $(F=34,440$, with Sig. $=0,000<0,05)$; and there are significant correlation between interest in learning with science concept understanding $($ Sig. $=0,000<0,05)$.
\end{abstract}

Keywords: guided inquiry learning, science concept understanding, interest in learning

\begin{abstract}
ABSTRAK: Penelitian ini bertujuan untuk mengetahui pengaruh model pembelajaran Inkuiri Terbimbing terhadap pemahaman konsep IPA dengan mengontrol minat belajar. Rancangan penelitian yang digunakan adalah non-equivalent post-test only control group design. Populasi dalam penelitian ini adalah siswa kelas V SD Negeri di Gugus XIII Kecamatan Buleleng tahun pelajaran 2015/2016. Sampel diambil dengan teknik random sampling. Data yang telah dikumpulkan dianalisis dengan uji Anakova 1 jalur 1 kovariabel. Hasil penelitian menunjukkan bahwa (1) terdapat perbedaan yang signifikan pemahaman konsep IPA antara kelompok siswa yang dibelajarkan dengan model pembelajaran Inkuiri Terbimbing dan kelompok siswa yang dibelajarkan dengan pembelajaran konvensional $(F=39,297$, dengan Sig. $=0,000<0,05)$; (2) terdapat perbedaan yang signifikan pemahaman konsep IPA antara kelompok siswa yang dibelajarkan dengan model pembelajaran Inkuiri Terbimbing dan kelompok siswa yang dibelajarkan dengan pembelajaran konvensional setelah mengontrol minat belajar ( $F=34,440$, dengan Sig. $=0,000<0,05)$; dan (3) terdapat korelasi yang signifikan antara minat belajar dengan pemahaman Konsep IPA (Sig. $=0,000<0,05$ ). Dengan demikian, terdapat pengaruh model pembelajaran Inkuiri Terbimbing terhadap pemahaman konsep IPA dengan mengontrol minat belajar.
\end{abstract}

Kata kunci: pembelajaran Inkuiri Terbimbing, pemahaman konsep IPA, minat belajar 
Pendidikan merupakan kebutuhan paling esensial bagi setiap manusia. Pendidikan adalah pembelajaran pengetahuan, keterampilan, dan kebiasaan sekelompok orang yang ditransfer dari satu generasi ke generasi berikutnya melalui pengajaran, pelatihan, atau penelitian. Pendidikan akan memberi perbekalan kecakapan-kecakapan hidup di masa yang akan datang. Pendidikan dapat diartikan sebagai suatu proses dengan metode-metode tertentu sehingga seseorang memperoleh pengetahuan, pemahaman, dan cara tingkah laku sesuai dengan kebutuhan.

Penyelenggaraan pendidikan yang bermutu akan menghasilkan sumber daya manusia yang bermutu dan mempunyai daya saing. Pembangunan nasional dibidang pengembangan sumber daya manusia Indonesia yang berkualitas melalui pendidikan merupakan upaya yang sungguh-sungguh dan terus-menerus dilakukan untuk mewujudkan manusia Indonesia seutuhnya. Sumber daya yang berkualitas akan menentukan mutu kehidupan pribadi, masyarakat, dan bangsa dalam rangka mengantisipasi, mengatasi persoalan-persoalan, dan tantangan-tantangan yang terjadi dalam masyarakat pada kini dan masa depan.

IPA merupakan cabang pengetahuan yang berawal dari fenomena alam. IPA berhubungan dengan cara mencari tahu tentang alam secara sistematis sehingga IPA bukan hanya penguasaan kumpulan pengetahuan yang berupa fakta-fakta, konsepkonsep atau prinsip-prinsip saja tetapi juga merupakan suatu proses penemuan (Trianto, 2007:99). Karakteristik pendidikan IPA yang digariskan oleh Departemen Pendidikan Nasional sejalan dengan pandangan para pakar pendidikan IPA di tingkat Internasional. IPA merupakan perwujudan dari suatu hubungan dinamis yang mencakup tiga faktor utama, yaitu: IPA sebagai suatu proses dan metode (science as methods and processes); IPA sebagai produk-produk pengetahuan (science as body of knowledge), dan IPA sebagai nilai-nilai (science as values).

Dalam wacana seperti itu, IPA bukan hanya cara bekerja, melihat, dan cara berpikir, melainkan science as a way of knowing. Artinya, IPA sebagai proses juga dapat meliputi kecenderungan sikap atau tindakan, keingintahuan, kebiasaan berpikir, dan seperangkat prosedur. Sementara nilai-nilai (values) IPA berhubungan dengan tanggung jawab moral, nilai-nilai sosial, manfaat IPA untuk kehidupan manusia, serta sikap dan tindakan (misalnya, keingintahuan, kejujuran, ketelitian, ketekunan, hati-hati, toleran, hemat, dan pengambilan keputusan).

Berdasarkan hasil observasi yang telah dilakukan di SD Negeri Gugus XIII Kecamatan Buleleng adapun beberapa masalah yang ditemui, yaitu Pertama, pembelajaran yang dilakukan guru cenderung masih menggunakan model pembelajaran konvensional. Model pembelajaran ini lebih menekankan proses pembelajaran yang berpusat pada guru yang membuat siswa menjadi pasif dalam belajar karena hanya mendengarkan dan mencatat informasi dari guru, tanpa ada aktivitas lain yang menggerakkan tubuh sewaktu belajar sehingga pembelajaran yang berlangsung menjadi kurang efektif yang akan berpengaruh pada pemahaman konsep siswa karena siswa tidak dapat membangun sendiri pengetahuannya. Kedua, ada beberapa siswa yang kurang antusias dalam mengikuti proses pembelajaran, hal tersebut dikarenakan pembelajaran yang terapkan kurang menarik sehingga berdampak pada rendahnya minat belajar siswa terhadap pembelajaran yang berlangsung. Ketiga, kurang bervariasinya sumber belajar yang digunakan oleh guru karena hanya memakai satu buku sebagai sumber belajar.

Berdasarkan identifikasi faktor penyebab masalah yang timbul, maka diperlukan suatu model pembelajaran yang dapat membuat pembelajaran terasa menyenangkan serta dapat meningkatkan kualitas pembelajaran IPA yang nantinya benar-benar berguna bagi siswa. Untuk meningkatkan kualitas pembelajaran IPA, maka pemahaman konsep terhadap objek IPA mutlak diperlukan, dan hal ini sangat penting. Teori konstruktivisme memandang bahwa untuk dapat memahami konsep IPA, maka keaktifan siswa untuk membangun pengetahuannya sendiri sangat diperlukan. Suatu konsep disusun berdasarkan konsepkonsep sebelumnya, dan akan menjadi dasar bagi konsep-konsep selanjutnya, sehingga pemahaman yang salah terhadap suatu konsep, akan berakibat pada kesalahan pemahaman terhadap konsep-konsep selanjutnya. 
Dalam peningkatan pemahaman konsep IPA siswa, seorang tenaga pendidik perlu melakukan upaya yang inovatif dalam pembelajaran yang membuat siswa tertarik untuk belajar IPA. Salah satu model pembelajaran yang efektif untuk digunakan adalah model pembelajaran inkuiri. Pembelajaran inkuiri sangat sesuai dengan pembelajaran IPA. Menurut W. Gulo (dalam Anam, 2015:11) mengemukakan bahwa, pembelajaran inkuiri berarti suatu rangkaian kegiatan belajar yang melibatkan secara maksimal seluruh kemampuan siswa untuk mencari dan menyelidiki secara sistematis, kritis, logis, analitis, sehingga mereka dapat merumuskan sendiri penemuannya dengan penuh percaya diri. Namun diketahui bersama bahwa siswa diusia sekolah dasar masih perlu bimbingan dari guru dalam melakukan kegiatan. Pembelajaran inkuiri yang sesuai dengan anak-anak diusia sekolah dasar adalah pebelajaran inkuiri terbimbing, karena anakanak diusia sekolah dasar belum berpengalaman dengan pembelajaran inkuiri (Suastra, 2009). Menurut Bonnstetter (dalam Anam, 2015:17) Model pembelajaran Inkuiri Terbimbing (guided inquiry) yaitu suatu model pembelajaran inkuiri yang dalam pelaksanaannya guru menyediakan bimbingan atau petunjuk cukup luas kepada siswa degan memberikan suatu permasalahan untuk dibuatkan pemecahan masalahnya oleh siswa dengan dibimbing oleh guru.

Minat sangat besar pengaruhnya terhadap belajar. Menurut Sardini (2013:3) "Minat belajar dapat kita definisikan sebagai ketertarikan dan kecenderungan yang tetap untuk memperhatikan dan terlibat dalam aktivitas belajar karena menyadari pentingnya atau bernilainya hal yang ia pelajari" Dengan demikian, minat belajar sangat menentukan keberhasilan siswa dalam proses pembelajaran, termasuk dalam pemahaman konsep IPA. Jika minat belajar siswa tinggi, maka mereka akan cenderung lebih mudah dalam memahami konsep IPA. Begitu sebaliknya, jika minat belajar siswa rendah, maka mereka akan cenderung lebih sulit dalam memahami konsep IPA.

Adapun tujuan dari penelitian ini adalah (1) menganalisis perbedaan pemahaman konsep IPA antara kelompok siswa yang dibelajarkan dengan model pembelajaran Inkuiri Terbimbing dan yang tidak dibelajarkan dengan model pembelajaran Inkuiri Terbimbing, (2) menganalisis perbedaan pemahaman konsep IPA antara kelompok siswa yang dibelajarkan dengan model pembelajaran Inkuiri Terbimbing dan yang tidak dibelajarkan dengan model pembelajaran Inkuiri Terbimbing setelah mengontrol minat belajar, dan (3) menganalisis korelas antara minat belajar dengan pemahaman konsep IPA pada siswa kelas V SD Negeri Gugus XII Kecamatan Buleleng Tahun Pelajaran 2015/2016.

\section{METODE}

Penelitian ini merupakan penelitian eksperimen semu (quasi experiment) yang dilaksanakan di Gugus XIII, Kecamatan Buleleng dengan jumlah populasi 106 siswa. Penelitian ini menggunakan rancangan non equivalent post-test only control group design. Berdasarkan karakteristik populasi dan tidak bisa dilakukannya pengacakan individu, maka pengambilan sampel pada penelitian ini dilakukan dengan teknik group random sampling. Sebelum menentukan sampel penelitian, populasi tersebut diuji kesetaraannya berdasarkan nilai UTS IPA semester ganjil dengan Anava 1 jalur. Berdasarkan hasil uji keserataraan yang dilakukan dengan program SPSS 16.0 for windows, diketahui bahwa kemampuan siswa di gugus tersebut telah setara.

Setelah dilakukan uji kesetraan, selanjutnya sampel dalam penelitian ini ditetapkan 2 kelas yang setara yaitu kelas V SD N 1 Banjar Tegal yang berjumlah 29 orang siswa sebagai kelompok eksperimen dan kelas V SD N 1 Baktiserga yang berjumlah 28 orang siswa sebagai kelompok kontrol. Variabel dalam penelitian ini terdiri atas variabel independent yakni model pembelajaran, variabel dependent yakni pemahaman konsep IPA, dan kovariabel minat belajar.

Metode pengumpulan data yang digunakan adalah metode tes dan kuesioner. Tes yang digunakan yaitu tes pemahaman konsep IPA, sedangkan kuesioner yang digunakan adalah kuesioner minat belajar. Data yang dikumpulkan dianalisis menggunakan analisis statistik deskriptif, 
anava 1 jalur, Anakova 1 jalur 1 kovariabel dan product moment.

\section{HASIL DAN PEMBAHASAN}

Hasil

Berdasarkan analisis data yang dilakukan terhadap nilai pemahaman konsep IPA, diperoleh hasil seperti yang tersaji pada Tabel 1.

Berdasarkan Tabel 1, diketahui bahwa rata-rata nilai pemahaman konsep IPA pada siswa yang dibelajarkan dengan model pembelajaran Inkuiri Terbimbing adalah 81,82 dengan kategor sangat tinggi. Sedangkan ratarata nilai pemahaman konsep IPA pada siswa yang dibelajarkan dengan pembelajaran konvensional sebesar 62,57 dengan kategori tinggi. Hal ini berarti bahwa nilai rata-rata pemahaman konsep IPA siswa yang dibelajarkan dengan pembelajaran konvensional termasuk dalam kategori tinggi. Rata-rata dari hasil ini mengindikasikan bahwa hasil akhir pemahaman konsep IPA antara siswa yang dibelajarkan dengan model pembelajaran Inkuiri Terbimbing dan siswa yang dibelajarkan dengan pembelajaran konvensional memiliki tingkat pemahaman konsep yang berbeda. Dengan kata lain, kelompok siswa yang dibelajarkan dengan model pembelajaran Inkuiri Terbimbing memiliki tingkat pemahaman konsep IPA yang lebih baik dibandingkan dengan kelompok siswa yang dibelajarkan dengan pembelajaran konvensional.

Tabel 1. Deskripsi Nilai Pemahaman Konsep IPA

\begin{tabular}{cccccccc}
\hline Kelompok & Rata-rata & Median & Modus & $\begin{array}{c}\text { Standar } \\
\text { Deviasi }\end{array}$ & Varians & $\begin{array}{c}\text { Nilai } \\
\text { Minimum }\end{array}$ & $\begin{array}{c}\text { Nilai } \\
\text { Maksimum }\end{array}$ \\
\hline $\mathrm{A}_{1} \mathrm{Y}$ & 81,82 & 83 & 83 & 9,60 & 92,21 & 60 & 100 \\
$\mathrm{~A}_{2} \mathrm{Y}$ & 62,57 & 63 & 56 & 1,33 & 178,18 & 40 & 86 \\
\hline
\end{tabular}

Keterangan:

$\mathrm{A}_{1} \mathrm{Y}=$ Hasil kelompok yang menggunakan Inkuiri Terbimbing

$\mathrm{A}_{2} \mathrm{Y}=$ Hasil kelompok yang menggunakan pembelajaran konvensional

Sebelum dilakukan pengujian hipotesis, terlebih dahulu dilakukan uji prasyarat yaitu uji normalitas, uji homogenitas, dan uji linieritas. Berdasarkan hasil pengujian prasyarat diperoleh bahwa data pemahaman konsep IPA berdistribusi normal, varians kedua kelompok homogen, dan regresi linier. Setelah semua asumsi terpenuhi, selanjutnya dilakukan pengujian hipotesis ke-1 dengan uji Anava 1 jalur, hipotesis ke-2 dengan uji Anakova 1 jalur 1 kovariabel, dan hipotesis ke-3 diuji dengan korelasi product moment. Hasil pengujian hipotesis dengan uji Anava 1 jalur tersaji pada Tabel 2.

Tabel 2. Hasil Uji Anava 1 jalur ( Uji hipotesis ke-1)

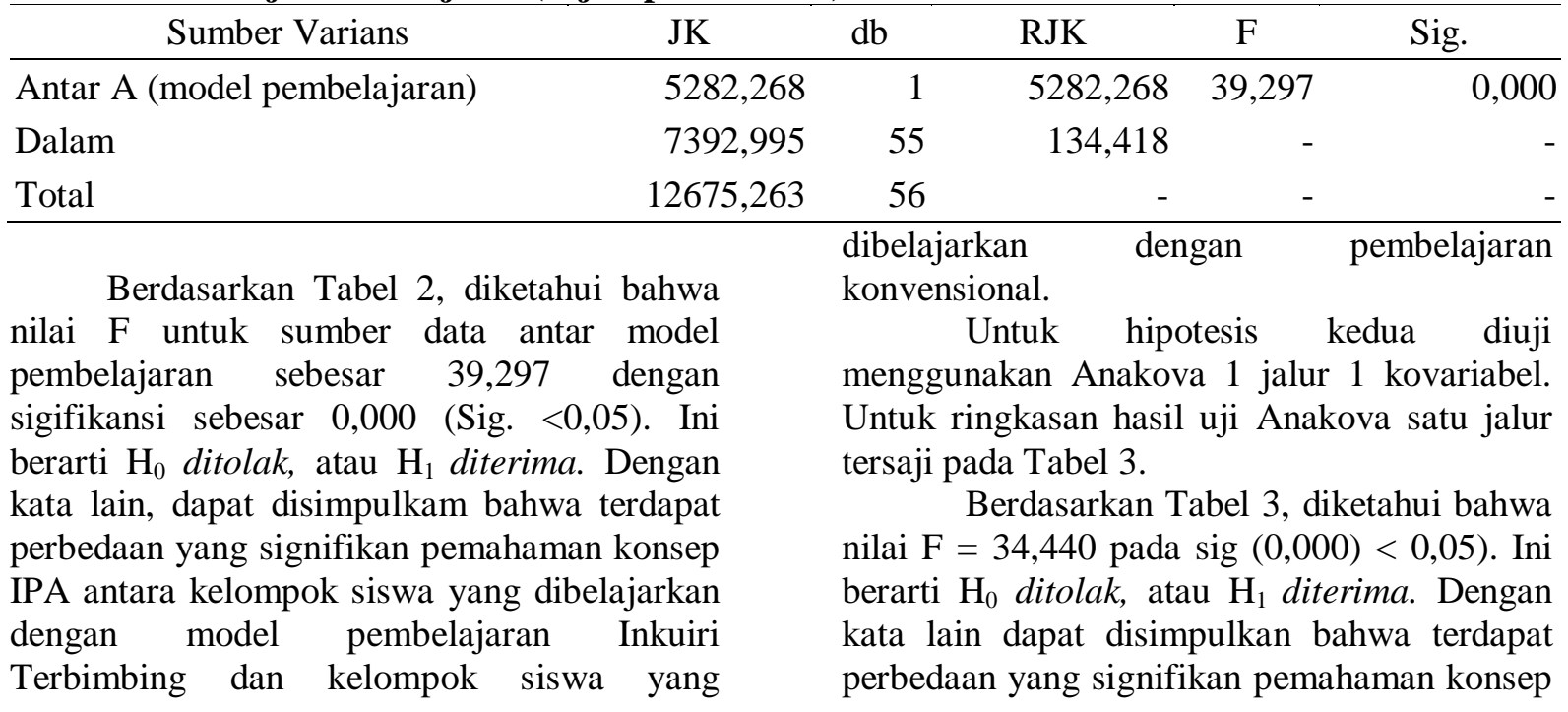


IPA antara kelompok siswa yang dibelajarkan dengan model pembelajaran Inkuiri Terbimbing dan kelompok siswa yang dibelajarkan dengan pembelajaran konvensional setelah mengontrol minat belajar.

Untuk hipotesis ketiga diuji menggunakan korelasi product moment. Berdasarkan hasil uji korelasi pemahaman konsep IPA dengan minat belajar siswa menggunakan product moment, tampak bahwa koefisien korelasi minat belajar positif (searah) terhadap pemahaman konsep IPA. Koefisien korelasi product moment menunjukkan nilai sebesar 0,457 dengan signifikansi sebesar 0,000 . Ini berarti $\mathrm{H}_{0}$ ditolak, atau $\mathrm{H}_{1}$ diterima. Dengan demikian, dapat disimpulkan bahwa terdapat korelasi yang signifikan antara minat belajar dengan pemahaman konsep IPA.

Tabel 3. Ringkasan Hasil Uji Hipotesis Kedua

\begin{tabular}{crrrrr} 
Sumber Varians & \multicolumn{1}{c}{$\mathrm{JK}$} & $\mathrm{db}$ & \multicolumn{1}{c}{ RJK } & \multicolumn{1}{c}{$\mathrm{F}$} & \multicolumn{1}{c}{ Sig. } \\
\hline X & 12070,922 & 1 & 12070,922 & 11,210 & 0,001 \\
A & 3904,553 & 1 & 3904,553 & 34,440 & 0,000 \\
Dalam & 6122,073 & 54 & 113,372 & - & - \\
Total & 12675,263 & 56 & - & - & - \\
\hline
\end{tabular}

\section{Pembahasan}

Berdasarkan hasil analisis data, ada beberapa temuan yang diperoleh. Pertama terdapat perbedaan yang signifikan pemahaman konsep IPA antara kelompok siswa yang dibelajarkan dengan model pembelajaran Inkuiri Terbimbing dan kelompok siswa yang dibelajarkan dengan pembelajaran konvensional. Perbedaan pemahaman konsep IPA yang signifikan ini dapat dijelaskan karena pembelajaran dengan model pembelajaran Inkuiri Terbimbing memberikan peluang besar kepada siswa untuk berperilaku aktif terlibat langsung dalam proses pembelajaran dalam menemukan suatu pemahaman yang baru. Pembelajaran dengan model Inkuiri Terbimbing dalam proses pembelajaran guru harus memberikan pengarahan dan bimbingan kepada siswa dalam melakukan kegiatan-kegiatan sehingga siswa yang berpikir lambat. Guru memberikan masalah kepada siswa, kemudian siswa diarahkan untuk mengajukan rumusan masalah dari permasalahan yang ada. Setelah rumusan masalah ada kemudian siswa membuat jawaban sementara dari rumusan masalah yang diajukan. Dalam menyelesaikan masalah siswa juga memerlukan buku-buku sumber untuk membantu menyelesaikan masalah yang ada. Dalam menyelesaikan masalah yang diberikan siswa melakukan percobaan. Setelah melakukan percobaan siswa membuat kesimpulan dari hasil percobaan sudah dilakukan. Untuk mencapai kesimpulan yang akurat sebaiknya guru mampu menunjukkan pada siswa data mana yang relevan. Dalam pembelajaran dengan model Inkuiri Terbimbing, bimbingan yang diberikan kepada siswa tidak hanya diberikan secara langsung oleh guru, dapat juga dengan memberikan LKS saat siswa melaksanakan diskusi dan dapat juga dengan menyediakan media pembelajaran saat proses pembelajaran. Dengan demikian siswa juga akan diarahkan untuk dapat menemukan sendiri pemahamannya terhadap materi-materi yang dipelajari yang nantinya pemahaman tersebut akan dapat lebih lama diingat oleh siswa.

Hasil penelitian ini didukung oleh hasil penelitian dari Sahabiyah (2013) dan Susilawati (2015) dimana hasil penelitiannya menunjukkan bahwa model pembelajaran Inkuiri Terbimbing cenderung lebih baik dibandingkan dengan pembelajaran konvensional.

Setelah pengontrolan terhadap minat belajar perbedaan yang signifikan ini dapat dikatakan sebagai hasil dari pengaruh model pembelajaran Inkuiri Terbimbing dan pembelajaran konvensional terhadap pemahaman konsep IPA atau dengan kata lain minat belajar tidak mempengaruhi perbedaan pemahaman konsep IPA siswa pada kelompok kontrol maupun kelompok eksperimen. Secara teoritis kita ketahui bahwa model pembelajaran Inkuiri Terbimbing dapat 
meningkatkan pemahaman konsep IPA siswa. Selain model pembelajaran tentu ada hal-hal lain yang juga berpengaruh terhadap pemahaman konsep IPA siswa, salah satunya minat belajar. Minat belajar siswa setiap individu adalah berbeda-beda, untuk kelas ekperimen dan kelas kontrol setiap siswa pasti akan memiliki minat belajar yang berbeda. Minat mampu menumbuhkan kemauan belajar serta perhatian siswa terhadap materi yang sedang diajarkan oleh guru.

Sukardi (dalam Susanto, 2013) mengemukakan bahwa "minat dapat diartikan sebagai suatu kesukaan, kegemaran atau kesenangan akan sesuatu". Adapun Sardiman (Susanto, 2013), mengemukakan minat adalah suatu kondisi yang terjadi apabila seseorang atau individu melihat ciri-ciri atau arti sementara situasi dihubungkan dengan keinginan atau kebutuhan-kebutuhan sendiri. Crow and crow (dalam Nurkancana, 2007), istilah minat dapat diartikan sebagai suatu tenaga pendorong yang menyebabkan seseorang memiliki rasa suka atau menaruh perhatian kepada orang-orang, benda atau suatu aktivitas. Seseorang yang menaruh perhatian atau rasa suka terhadap suatu benda maupun aktivitas maka seseorang akan memperhatikannya dengan baik dan secara berkesinambungan, begitupula bila seseorang menaruh perhatian atau rasa suka terhadap mata pelajaran terjadi kecenderungan seseorang tersebut akan memerhatikan mata pelajaran dengan baik. Namun sebaliknya jika siswa tidak berminat, maka perhatian pada mata pelajaran yang sedang diajarkan biasanya akan malas dan enggan untuk mengerjakan apa yang ditugaskan oleh gurunya. Bila siswa menaruh perhatian pada mata pelajaran tertentu dengan baik, maka itu akan dapat memengaruhi proses belajarnya.

Proses pembelajaran yang menggunakan model pembelajaran Inkuiri Terbimbing memberikan peluang besar kepada siswa untuk berpartisipasi aktif dalam proses pembelajaran. Pembelajaran dengan model Inkuiri Terbimbing mengajak siswa berperan aktif dalam menggali dan menemukan pemahaman baru terhadap materi dalam IPA namun tetap dalam bimbingan guru. Jika siswa dihadapkan dengan situasi belajar yang menarik dan melibatkan mereka dalam pembelajaran, minat belajar yang mereka miliki untuk mengikuti pelajaran akan tinggi.
Hasil penelitian ini didukung oleh hasil penelitian Adnyana (2015) yang menyatakan bahwa setelah adanya pengendalian variabel minat belajar terdapat perbedaan kemampuan berpikir kritis yang signifikan antara siswa yang pembelajarannya menggunakan media lingkungan dengan siswa yang pembelajarannya tidak menggunakan media lingkungan.

Berbeda halnya dengan pembelajaran konvensional, yang dimana siswa akan lebih pasif dalam pembelajaran. Guru lebih mendominasi dalam pembelajaran, yang artinya siswa hanya mendapat pengetahuan baru yang berasal dari guru dan buku saja tanpa diberikan kesempatan untuk menemukan sendiri pengetahuannya. Hal tersebut menyebabkan siswa kurang maksimal dalam pembelajaran karena suasana belajar yang kurang menarik sehingga siswa menjadi kurang berminat dalam mengikuti proses pembelajaran.

Dalam hal belajar, minat mempunyai peranan yang sangat penting dalam proses belajar mengajar. Oleh karena itu, seorang guru hendaknya harus selalu berusaha untuk menumbuhkan dan meningkatkan minat siswa terhadap pelajaran yang diajarkan. Siswa yang memiliki minat belajar tinggi akan cenderung untuk melakukan setiap tugas atau pekerjaan yang diberikan oleh guru walaupun pekerjaan tersebut relatif sulit. Usaha keras dan gigih dari siswa yang memiliki minat belajar tinggi akan mengantarkan siswa tersebut untuk lebih mudah dan cepat memahami konsep-konsep dalam pembelajaran IPA dibandingkan dengan siswa yang memiliki minat belajar rendah. Hasil penelitian ini didukung oleh hasil penelitian Hermawati (2012) yang menyatakan bahwa, siswa dengan minat belajar yang rendah akan berpengaruh pada proses pembelajaran yang berlangsung. Ketiadaan minat terhadap pelajaran menjadi penyebab kurang bersemangatnya siswa dalam melakukan aktivitas pembelajaran.

Dengan demikian, dapat disimpulkam bahwa minat belajar memiliki korelasi dengan pemahaman konsep IPA.

\section{SIMPULAN}

Hasil pengujian terhadap ketiga hipotesis yang diajukan pada penelitian ini 
menghasilkan simpulan sebagai berikut. (1) Terdapat perbedaan yang signifikan pemahaman konsep IPA antara kelompok siswa yang dibelajarkan dengan model pembelajaran Inkuiri Terbimbing dan kelompok siswa yang dibelajarkan dengan pembelajaran konvensional pada siswa kelas $\mathrm{V}$ SD Negeri Gugus XIII Kecamatan Buleleng Tahun Pelajaran 2015/2016 ( F = 39,297; Sig.< $0,05)$. Hal ini ditunjukkan oleh rata-rata nilai pemahaman konsep IPA pada siswa yang dibelajarakan dengan model pembelajaran Inkuiri Terbimbing adalah sebesar 81,82, sedangkan rata-rata nilai pemahaman konsep IPA pada siswa yang tidak dibelajarkan dengan model pembelajaran Inkuiri Terbimbing adalah sebesar 62,57. Dengan demikian, rata-rata nilai pemahaman konsep IPA pada siswa yang dibelajarkan dengan model pembelajaran Inkuiri Terbimbing lebih besar dari rata-rata nilai pemahaman konsep IPA pada siswa yang tidak dibelajarkan dengan model pembelajaran Inkuiri Terbimbing $(81,82>62,57)$. (2) Terdapat perbedaan yang signifikan pemahaman konsep IPA antara kelompok siswa yang dibelajarkan dengan model pembelajaran Inkuiri Terbimbing dan kelompok siswa yang dibelajarkan dengan pembelajaran konvensional setelah mengontrol minat belajar pada siswa kelas V SD Negeri Gugus XIII Kecamatan Buleleng Tahun Pelajaran 2015/2016 dengan nilai $(F=39,297$; Sig. $<$ $0,05)$. (3) Terdapat korelasi yang signifikan antara minat belajar dengan pemahaman konsep IPA pada siswa kelas V SD Negeri Gugus XIII Kecamatan Buleleng Tahun Pelajaran 2015/2016 dengan hasil pengujian menunjukkan korelasi yang signifikan minat belajar dengan pemahaman konsep IPA $\left(\mathrm{r}_{\mathrm{xy}}=\right.$ 0,457; Sig. <0,05).

\section{DAFTAR RUJUKAN}

Adnyana, Surya. 2015. "Pengaruh Pemanfaatan Lingkungan Sekitar Sebagai Media Pembelajaran IPA Terhadap Kemampuan Berfikir Kritis Dengan Kovariabel Miant Belajar Pada Siswa SD Kelas VI Gugus II Kecamatan Sukasada Kabupaten Buleleng". Tesis (tidak diterbitkan). Program studi pendidikan dasar program pascasarjana UNDIKSHA.

Anam, Khoirul. 2015. Pembelajaran Berbasis Inkuiri (Metode dan Aplikasi). Yogyakarta: Pustaka Pelajar.

Hermawati, Manik IW. 2012. "Pengaruh Model Pembelajaran Inkuiri terhadap Penguasan Konsep Biologi dan Sikap Ilmiah Siswa SMA Ditinjau dari Minat Belajar Siswa". Tesis (tidak diterbitkan) Program Studi Pendidikan Sains Pascasarjana Universitas Pendidikan Ganesha.

Nurkancana, Wayan. 2007. Buku Ajar Psikologi Pendidikan. Singaraja: Undiksha.

Sabahiyah. 2013. "Pengaruh Model Pembelajaran Inkuiri Terbimbing Terhadap Keterampilan Proses Sains dan Penguasaan Konsep IPA Siswa Kelas V Gugus 03 Wanasaba Lombok Timur". Pascasarjana Undiksha. Volume 3. Tersedia pada http://download.portalgaruda.org/article. php?article (diakses tanggal 15 Mei 2016).

Sardini. 2013. "Pengaruh Minat Belajar Terhadap Hasil Belajar Pelajaran Ekonomi Siswa Kelas Xi IPS Man Pontianak". Tersedia pada http://download.portalgaruda.org/article. php?article $=112331 \&$ val $=2338$ (diakses tanggal 11 Januari 2016).

Suastra, I.W. 2009. Pembelajaran Sains Terkini Mendekati Siswa dengan Lingkungan Alamiah dan Sosial Budayanya. Singaraja: Undiksha.

Susanto, Ahmad. 2013. Teori Belajar \& Pembelajaran di Sekolah Dasar. Jakarta: Prenadamedia Group.

Susilawati. 2015. "Pengaruh Model Pembelajaran Inkuiri Terbimbing Terhadap Keterampilan Proses Sains Siswa". Jurnal Tadris IPA Biologi FITK IAIN Mataram. Volume VIII, 
Nomor 1. Tersedia pada https://www. google.co.id /url?dGo (diakses tanggal 15 Mei 2016).

Tangkas, I Made. 2012. Pengaruh Implementasi Model Pembelajaran Inkuiri Terbimbing Terhadap Kemampuan Pemahaman Konsep dan Keterampilan Proses Sains Siswa Kelas $\mathrm{X}$ Sman 3 Amlapura. Jurnal Inkuri. Tersedia pada https://www.google.co.id/url?sa=t\&rct=j $\& \mathrm{q}=\& \mathrm{esrc}=\mathrm{s} \&$ source $=$ web $\& \mathrm{~cd}=1 \& \mathrm{cad}=$ rja\&uact $=8 \&$ ved $=0$ ahUKEwiwycvMyo7 NAhVBFZQKHTvyBfAQFggZMAA\& url=http\%3A\%2F\%2Fpasca.undiksha.ac .id\%2Fejournal\%2Findexphp\%2Fjurnal _ipa $\% 2$ Farticle $\% 2$ Fdownload $\% 2 F 410 \%$ 2F202\&usg=AFQjNE1Nz0cuGZxBRk0 $7 \mathrm{~m} 4$ oouia7W(diakses pada 15 Januari 2016).

Trianto. 2007. Model Pembelajaran Terpadu Dalam Teori dan Praktek. Jakarta: Prestasi Pustaka. 